\title{
Distal renal tubular acidosis without renal impairment after use of tenofovir: a case report
}

\author{
Kentaro Iwata ${ }^{1 *}$, Manabu Nagata', Shuhei Watanabe ${ }^{2}$ and Shinichi Nishi ${ }^{2}$
}

\begin{abstract}
Background: Tenofovir, one of antiretroviral medication to treat human immunodeficiency virus (HIV) infection, is known to cause proximal renal tubular acidosis such as Fanconi syndrome, but cases of distal renal tubular acidosis had never been reported.
\end{abstract}

Case presentation: A 20-year-old man with HIV infection developed nausea and vomiting without diarrhea after starting antiretroviral therapy. Arterial blood gas revealed non-anion-gap metabolic acidosis and urine test showed positive urine anion gap. Tenofovir, one of antiretroviral medicine the patient received, was considered to be the cause of this acidosis and all antiretroviral drugs were discontinued. Symptoms disappeared promptly without recurrence of symptoms after resuming antiretroviral medications without tenofovir.

Conclusion: Distal renal tubular acidosis caused by tenofovir, without renal impairment is very rare. Since causes of nausea and vomiting among HIV/AIDS patients are very diverse, awareness of this phenomenon is useful in diagnosing and managing the problem.

Keywords: HIV, Renal tubular acidosis, Tenofovir, Case report

\section{Background}

Causes of nausea and vomiting among patients with human immunodeficiency virus (HIV) infection and/or acquired immune deficiency syndrome (AIDS) are diverse; gastrointestinal, neurological, endocrine causes to name a few [1]. Nephrotoxicity and proximal renal tubular acidosis (RTA) known as Fanconi syndrome are known and established side effect of tenofovir (TDF), a nucleotide analog [2-5]. One study reported that the incidence rate of moderate or severe renal insufficiency caused by tenofovir was 29.2 and 2.2 cases per 1000 person-year respectively [6]. Fanconi syndrome caused by tenofovir is rare and exact incidence rate is not known. Fanconi syndrome caused by tenofovir is usually associated with other manifestations such as worsening of glomerular filtration rate (GFR), proteinuria, hypophosphataemia, and glycosuria $[4,5]$.

\footnotetext{
* Correspondence: kentaroiwata1969@gmail.com

${ }^{1}$ Division of Infectious Diseases Therapeutics, Kobe University Graduate School of Medicine, Kusunokicho 7-5-2, Chuoku, Kobe, Hyogo, Japan 650-0017

Full list of author information is available at the end of the article
}

RTA can be differentiated into either distal or proximal, depending on the site of tubules affected. Both have normal serum anion gap, but distal RTA is characterized by positive urine anion gap $\left(\left[\mathrm{Na}^{+}+\mathrm{K}^{+}\right]_{\mathrm{u}}-\right.$ $\left[\mathrm{Cl}^{-}\right]_{\mathrm{u}}$ ), whereas proximal RTA has negative urine anion gap [7]. Major causes of distal RTA in adults is autoimmune diseases such as Sjögren's syndrome [7]. Medications such as ibuprofen are also known to cause distal RTA [8], but distal RTA caused by antiretroviral medications has never been reported to the best of our knowledge. We here present such a rare case of distal RTA most likely caused by tenofovir.

\section{Case presentation}

A 20-year-old man with HIV infection visited us with chief complaint of nausea and vomiting. He had been followed at our Infectious Diseases clinic. He had no past medical history otherwise, including opportunistic diseases. Two months after his initial visit, antiretroviral therapy (ART) was started with Truvada ${ }^{\circ}$ (tenofovir and emtricitabine), and raltegravir. His baseline $\mathrm{CD} 4+\mathrm{T}$ lymphocytes count before initiation of ART was $456 / \mu \mathrm{L}$ 
and RT-PCR for HIV-1 was $2.8 \times 10^{3}$ copies $/ \mathrm{mL}$. Other routine blood and urine tests were all normal. He stated that he had been adherent to ART. Six weeks after initiation of ART, he developed nausea and vomiting. He visited our Infectious Diseases clinic on the following day. He denied fever, headache, seizure, abdominal pain, or diarrhea. He also denied use of medications other than we prescribed, supplements, alcohol or any illicit drugs.

On physical examination, he appeared anxious. Blood pressure was $116 / 70 \mathrm{mmHg}$, pulse rate $95 / \mathrm{min}$, respiratory rate $18 / \mathrm{min}$, and body temperature $36.9{ }^{\circ} \mathrm{C}$. Rest of physical examination including thorough neurological examination was normal. On blood tests, complete blood counts $(\mathrm{CBC})$, electrolytes, liver and kidney function tests were all unremarkable (Table 1). Arterial blood gas showed pH 7.327, pCO2 $38.3 \mathrm{mmHg}$, bicarbonate $19.3 \mathrm{mmol} / \mathrm{L}$, and anion gap $13.9 \mathrm{mmol} / \mathrm{L}$. Spot urianalysis showed urine $\mathrm{pH} 5.5$, and urine sodium $160 \mathrm{mmol} / \mathrm{L}$, potassium $52 \mathrm{mmol} / \mathrm{L}$, chloride $48 \mathrm{mmol} /$ $\mathrm{L}$, with urine anion gap $\left(\left[\mathrm{Na}^{+}+\mathrm{K}^{+}\right]_{\mathrm{u}}-\left[\mathrm{Cl}^{-}\right]_{\mathrm{u}}\right)$ of $164 \mathrm{mmol} / \mathrm{L}$. Urine phosphorus was $138.4 \mathrm{mg} / \mathrm{dL}$, urine calcium was $31.9 \mathrm{mg} / \mathrm{dL}$, and urine $\beta 2$-microglobulin was $1268 \mu \mathrm{g} / \mathrm{L}$ (normal range 0-289). Urine was also positive for protein $(1+)$ and ketone $(3+)$. Urine specific

Table 1 Laboratory Data

\begin{tabular}{|c|c|c|c|}
\hline Variables & $\begin{array}{l}\text { Reference } \\
\text { Ranges, Adults }\end{array}$ & $\begin{array}{l}\text { On the day } \\
\text { of the visit }\end{array}$ & $\begin{array}{l}\text { Next } \\
\text { day }\end{array}$ \\
\hline While-cell count (per $\mathrm{mm}^{3}$ ) & $4000-8500$ & 5100 & \\
\hline Hemoglobin (g/dL) & $13.6-17$ & 14.7 & \\
\hline Platelet $\left(\right.$ per $\mathrm{mm}^{3}$ ) & $\begin{array}{l}130,000- \\
300,000\end{array}$ & 209,000 & \\
\hline Sodium (mmol/L) & $137-146$ & 136 & \\
\hline Potassium (mmol/L) & $3.5-4.7$ & 4.1 & \\
\hline Chloride (mmol/L) & $99-109$ & 103 & \\
\hline Calcium (mg/dL) & $8.8-10.1$ & 9.2 & \\
\hline Phosphorus (mg/dL) & $2.4-4.5$ & 4.1 & \\
\hline Albumin (g/dL) & $4.1-5$ & 5.2 & \\
\hline $\begin{array}{l}\text { Aspartate aminotransferase } \\
(\mathrm{AST})(\mathrm{U} / \mathrm{L})\end{array}$ & $13-31$ & 17 & \\
\hline $\begin{array}{l}\text { Alanine aminotransferase } \\
\text { (ALT) (U/L) }\end{array}$ & $8-34$ & 15 & \\
\hline Total bilirubin (mg/dL) & $0.3-1$ & 1.2 & \\
\hline $\begin{array}{l}\text { Blood Urea Nitrogen (BUN) } \\
(\mathrm{mg} / \mathrm{dL})\end{array}$ & $9-22$ & 19.3 & \\
\hline Creatinine (mg/dL) & $0.5-1.3$ & 0.59 & \\
\hline Blood gas & & (arterial) & (venous) \\
\hline $\mathrm{pH}$ & $7.38-7.46$ & 7.327 & 7.334 \\
\hline $\begin{array}{l}\text { Partial pressure of carbon } \\
\text { dioxide }\left(\mathrm{PaCO}_{2}\right)(\mathrm{mmHg})\end{array}$ & $32-46$ & 38.3 & 43.1 \\
\hline Bicarbonate $\left(\mathrm{HCO}_{3}^{-}\right)(\mathrm{mmol} / \mathrm{L})$ & $21-29$ & 19.5 & 22.3 \\
\hline Anion-gap (mmol/L) & $10-20$ & 13.9 & 12.3 \\
\hline
\end{tabular}

gravity was 1.032 with approximate urine osmolality of $1000 \mathrm{mOsm} / \mathrm{kg}$ [9]. Calculated urine osmolality (2 x $[\mathrm{Na}+\mathrm{K}])+[$ urea nitrogen in $\mathrm{mg} / \mathrm{dL}] / 2.8+$ [glucose in $\mathrm{mg} / \mathrm{dL}] / 18$ ) was $939 \mathrm{mOsm} / \mathrm{kg}$ [10], with approximate urine osmolal gap of $61 \mathrm{mOsm} / \mathrm{kg}$.

Non-anion-gap metabolic acidosis was considered to be the cause of his current symptoms, and medications were suspected as the causative agent. Intravenous hydration and antiemetic was provided and all antiretroviral agents were discontinued at once. On the following day, his symptoms disappeared. Venous blood gas revealed normalized bicarbonate (Table 1). Five days after this event, the patient re-started ART with Epzicom ' (abacavir and lamivudine), and ralteglavir. He remains on the latest regimen without further events. Four months after re-starting ART, his CD4+ T lymphocytes count increased to $648 / \mu \mathrm{L}$ with undetectable HIV-1RNA.

Tenofovir is known to cause drug induced Fanconi syndrome, but is usually associated with other manifestations, particularly worsening of glomerular filtration rate. However, our patient lacked these symptoms, and urine anion gap was positive, making proximal renal tubular acidosis such as Fanconi syndrome less likely.

In our case, acute onset nausea and vomiting without diarrhea, with non-anion-gap metabolic acidosis plus positive urine anion-gap, makes distal renal tubular acidosis most likely. The reason for lack of potassium abnormality in the patient remains unknown, but acute onset of symptoms and prompt treatment might have prevented significant potassium wasting, which is characteristic of most distal RTA. We consider this case is of distal RTA of unclassified type, with prompt improvement after cessation of causative agent; i.e. tenofovir. Since discontinuation of tenofovir was effective in prompt disappearance of symptoms and acidosis, and re-institution of lamivudine (analogous to emtricitabine. They are very similar both in structure and pharmacological properties) and raltegravir did not cause the recurrence of the symptoms, we considered tenofovir as the most likely cause of RTA in this patient. We obtained venous blood gas to ascertain the correction of acidosis since recent metaanalysis found that venous gas is comparable to arterial blood gas in evaluating $\mathrm{pH}$ [11].

This is the first case ever reported on such an occurrence as far as we know of. The exact mechanism of renal toxicity caused by tenofovir is unknown, but it is considered to be the result of proximal tubular toxicity [12]. Pathogenesis of distal RTA by tenofovir, as in our case, remains unknown. Diminished hydrogen adenosine phosphatase (H-ATPase) activity is the most common cause of distal RTA [13], and it might have occurred with use of tenofovir. Although not reported so far, 
other antiretroviral agents, particularly nucleoside/nucleotide analogs also might cause similar side effect. Further studies might reveal pathogenesis of this phenomenon, as well as the true incidence and significance of this side effect. In addition, use of newer and apparently safer agent, tenofovir alafenamide (TAF) may prevent this to occur [14].

\section{Conclusions}

We here present a rare case of distal RTA without renal impairment most likely caused by tenofovir. Since causes of nausea and vomiting among HIV/AIDS patients are very diverse, awareness of this phenomenon is useful in diagnosing and managing the problem.

\section{Abbreviations}

AIDS: Acquired immune deficiency syndrome; ART: Antiretroviral therapy; CBC: Complete blood counts; GFR: Glomerular filtration rate; H-ATPase: Hydrogen adenosine phosphatase; HIV: Human immunodeficiency virus; RNA: Ribonucleic acid; RTA: Renal tubular acidosis; TAF: Tenofovir alafenamide; TDF: Tenofovir

\section{Acknowledgments}

None.

\section{Funding}

Not applicable.

\section{Availability of data and materials}

This is a case report and there is no dataset for the analysis. Laboratory data on the case is available in our medical chart.

\section{Authors' contributions}

$\mathrm{Kl}, \mathrm{MN}$, and SW actually took care of the patient, and discussed the case equally. SN provided further insight particularly regarding metabolic and nephrological aspects, and contributed to the understanding and discussion of our case. Kl prepared the manuscript. All read and agreed with the final manuscript.

\section{Competing interests}

All authors declare that there is no competing interests.

\section{Consent for publication}

The patient of the current case provided a written informed consent to publish the case.

\section{Ethics approval and consent to participate}

Since this is a case report, the ethics committee of Kobe University Graduate School of Medicine exempted our report from the approval.

\section{Author details}

'Division of Infectious Diseases Therapeutics, Kobe University Graduate School of Medicine, Kusunokicho 7-5-2, Chuoku, Kobe, Hyogo, Japan 650-0017. ${ }^{2}$ Division of Nephrology and Kidney Center, Kobe University Graduate School of Medicine, Kusunokicho 7-5-2, Chuoku, Kobe, Hyogo, Japan650-0017.

Received: 19 May 2016 Accepted: 21 October 2016

Published online: 21 November 2016

\section{References}

1. Fauci AS, Lane HC. Human Immunodeficiency Virus Disease: AIDS and Related Disorders. In: Kasper DL et al., editors. Harrison's Principles of Internal Medicine. 19th ed. New York: McGraw-Hill Education; 2015.

2. Karras A, Lafaurie M, Furco A, Bourgarit A, Droz D, Sereni D, et al. Tenofovirrelated nephrotoxicity in human immunodeficiency virus-infected patients: three cases of renal failure, Fanconi syndrome, and nephrogenic diabetes insipidus. Clin Infect Dis. 2003;36(8):1070-3.
3. Atta MG, Stokes MB. ASN Clinical Pathological Conference. CJASN. 2013;8:882-90.

4. Hall AM, Bass P, Unwin RJ. Drug-induced renal Fanconi syndrome. QJM. 2014;107:261-9.

5. Luni FK, Khan AR, Prashar R, Vetteth S, Duggan JM. Fanconi Syndrome and Antiretrovirals: It Is Never Too Late. Am J Ther. 2016;23(2):e558-60.

6. Quesada PR, Esteban LL, García JR, Sánchez RV, García TM, Alonso-Vega GG, et al. Incidence and risk factors for tenofovir-associated renal toxicity in HIVinfected patients. Int J Clin Pharm. 2015;37(5):865-72.

7. DuBose Jr TD, et al. Acidosis and Alkalosis. In: Kasper DL, editor. Harrison's Principles of Internal Medicine. 19th ed. New York: McGraw-Hill Education; 2015.

8. Salter MD. Ibuprofen-Induced Hypokalemia and Distal Renal Tubular Acidosis: A Patient's Perceptions of Over-the-Counter Medications and Their Adverse Effects. Case Rep Crit Care. 2013;2013:875857.

9. Leech S, Penney MD. Correlation of specific gravity and osmolality of urine in neonates and adults. Arch Dis Child. 1987:62(7):671-3.

10. Dyck RF, Asthana S, Kalra J, West ML, Massey KL. A modification of the urine osmolal gap: an improved method for estimating urine ammonium. Am J Nephrol. 1990;10(5):359-62

11. Byrne AL, Bennett M, Chatterji R, Symons R, Pace NL, Thomas PS. Peripheral venous and arterial blood gas analysis in adults: are they comparable? A systematic review and meta-analysis. Respirology. 2014;19(2):168-75.

12. Lucey JM, Hsu P, Ziegler JB. Tenofovir-related Fanconi's syndrome and osteomalacia in a teenager with HIV. BMJ Case Reports. 2013; bcr2013008674. https:/www.ncbi.nlm.nih.gov/pmc/articles/PMC3736206/.

13. Emmett $\mathrm{M}$ and Kelepouris E. Overview and pathophysiology of renal tubular acidosis and the effect on potassium balance. UpToDate. [cited 2016 Sep 23]. last updated: Jun 30, 2015.

14. De Clercq E. Tenofovir alafenamide (TAF) as the successor of tenofovir disoproxil fumarate (TDF). Biochemical Pharmacology [Internet]. [cited 2016 May 18]; Available from: http://www.sciencedirect.com/science/article/pii/ S0006295216300697. Accessed 30 June 2015.
Submit your next manuscript to BioMed Central and we will help you at every step:

- We accept pre-submission inquiries

- Our selector tool helps you to find the most relevant journal

- We provide round the clock customer support

- Convenient online submission

- Thorough peer review

- Inclusion in PubMed and all major indexing services

- Maximum visibility for your research

Submit your manuscript at www.biomedcentral.com/submit
Biomed Central 